\title{
The Development of Career Learning Program with Modeling Techniques to Improve Student Career Awareness
}

\author{
Elsa Keumala ${ }^{1}$, Juntika Nurihsan, Amin Budiamin \\ Universitas Pendidikan Indonesia Bandung, Indonesia \\ elsakeumala@student.upi.edu ${ }^{1}$
}

\section{Article Information:}

Received June 12, 2018

Revised June 26, 2018

Accepted June 30, 2018

\section{Keywords:}

career guidance program, modeling, career awareness.

\begin{abstract}
The research is based on the lack of career awareness students in the elementary school so that the main problem that became the focus on this research is the development of career guidance program with modeling technique to improve the career awareness of student. The purpose of this study is to generate career guidance program with modeling technique to improve student career awareness. Research and development approach conducted through several steps, namely: needs assessment, program planning, implementation of program, evaluation, and follow-up. The data analysis technique was used Paired sample T-test to determine the impact of the program. The participant is the student at the fifth grade Al-Fityan elementary school Aceh in the year 2017/2018 which selected using purposive sampling. The self-developed career awareness instrument by researchers designed in the Likert scale with coefficient reliability 0,800 . The finding of a research states that main indicator of the successful program evaluation is the increasing of the level of an awareness. This research concludes that the program of the career guidance using the modeling technique is effective to improve the awareness of student career.
\end{abstract}

\section{INTRODUCTION}

The commencement of late childhood is marked by the inclusion of children in primary school education who have a new responsibility signal. The child is responsible for oneself and what is owned, so that many important potentials in the child as a basis for further development. The child needs to be aware of how to change and use the school experience to get information and better prepared to plan the future.

We know how children learn and prepare for the future, given the ever-changing needs of the twenty-first century that require individuals to be flexible thinkers, effective problem solvers, and lifelong learners, it is very important in childhood to gain a better understanding of career development process to better prepared for their future (Johnson, 2000). Primary school-aged children have an interest in "what I would do as an adult". Generally, children are concerned and interested in their work in the future and are eager to express their preferences and desires. So while there is little urgency for most children to make direct employment choices, it is important for them to develop a meaningful understanding of the relevance of career-based learning at school for their future.

How to cite :

E-ISSN:

Published by:

Available online:
Keumala, E., Nurihsan J., \& Budiamin A. (2018). The Development of Career Learning Program with Modeling Techniques to Improve Student Career Awareness. Islamic Guidance and Counseling Journal, 1(2), 53-61. https://doi.org/10.25217/igcj.v1i2.270

2614-1566

Institut Agama Islam Ma'arif NU (IAIMNU) Metro Lampung

https://journal.iaimnumetrolampung.ac.id/index.php/igcj 
The Development of Career Learning Program with Modeling Techniques to Improve Student Career Awareness

The cultivation of career awareness in the child from an early age should be emphasized, so the career is not just a job, but more than that the child in choosing and determining a career is the satisfaction for continuity throughout life. Children begin to think about how ability and interest will affect career decisions in the end. Career aims encourage children to develop an understanding of themselves, explore themselves with a variety of occupations, and help children avoid limiting educational and work options too early (Amundson, HarrisBowlsbey, \& Niles, 2005).

Career development in primary schools is largely ignored in the form of literature, practice, and professional training programs (Emmett, 1997). While more and more school counselor preparation programs include career counseling/development courses, few make adjustments for the needs of elementary school counselors in the future. This makes many primary school counselors lack the proper training and support to facilitate the development of primary school students' careers.

Career counseling in primary schools, only one article has been revealed in the investigation of career development in primary schools, hindering the development of a systematic career program for advanced students (Stroeher, 1994). Furthermore, comprehensive career development research still lacks focus. Some of the research that focuses on career aspirations, career interests, influence and career development of children, and career education programs (Stead \& Schultheiss, 2003). Most research reviews conclude that career development in childhood is a complex interaction between attributes, behavior and the environment.

Seen from the annual report of Indonesia (Unicef, 2012) accompanying data about 2.3 million children at 7-15 years are not going to school and about $42 \%$ of them are a dropout. Kemendikbud also accompanies data in 2015/2016 there are more than 1 million primary school dropout children. Regarding the dropout rate in Indonesia with primary school age is increasingly reinforcing so that career awareness is needed to be instilled in school settings. A study in Turkey through primary school students also shows results even though they were able to associate personal characteristics with careers but they are lack of knowledge about career implications and career management tasks (Nazl1, 2014).

Based on a preliminary study conducted with teachers at Al-Fityan Primary School, many students have not fully understood what they would like to do as adults later. According to the teacher at Al-Fityan school, students have not found the interest and talent that exist in the self-seen from the lack of understanding of students to themselves, especially on extracurricular activities conducted in schools. Students participate in selected extracurricular activities on invitation from friends or parental selections, and only a few choose extracurricular based on student's interest. Students' knowledge of a profession is only seen externally or the appearance of a profession, students do not understand the task of a profession.

The phenomenon that occurs in primary school students allegedly because the career guidance service in school has not touched many needs of students. The absence of career guidance service in school makes the needs of students on career is still not optimal so the school needs a career guidance services to students as one form of achievement of students' need that must be invested in the form of self-belief, knowledge about career information, and ideas become the main focus of career guidance in primary school.

The career guidance service in the context of primary school education is an effort to help students know themselves and optimize their potential, thus putting the importance of counseling and guidance services in schools to improve students' recognition, understanding, and self-awareness.

Super identifies the career of a child in the primary school age period including the growth stage (Muro \& Kottman, 1995). The most dominant stage of career growth in primary 
school-aged children is the development of fantasy, interest, and career ability. Super career growth is designed for future planning, enhancing personal control over individual lives, developing awareness of the importance of school achievement and work, and gaining a competent work attitude. In accordance with the Super scheme at the stage of growth, the child will go through various learning activities experiences when developing greater selfawareness.

Muro and Kottman declared career in primary school focused on self-awareness and career awareness (self and career awareness) (Muro \& Kottman, 1995). Self-awareness takes the form of awareness that students have of themselves, called self-knowledge. While career awareness is more focused on career exploration and the introduction of existing position within the community. Suherman also states that career awareness of primary school-aged children is a form of career maturity since children are still at the level of consciousness (Suherman, 2013).

As the phenomenon of career awareness at the age of primary school, it describes a process of career development that occurs and is experienced in the life and development of human generally. The task of a child's career is similar to the national career at the level of kindergarten through sixth grade of primary school published by the National Occupational Information Coordinating Committee (Worzbyt, O'Rourke, \& Dandeneau, 2003). Child career goals are grouped into three career orientations, namely self-knowledge, education and career exploration, and career planning.

Self-knowledge consists of self-concept recognition, awareness of interacting skills, and awareness of growth and choice. Career education and exploration include achievement awareness, work-relationship awareness and learning, understanding skills and use of career information awareness, and personal and work responsibilities awareness. Career planning consists of understanding making decision awareness, relationships and the role of life awareness, job differences and appropriate choice of roles of man and woman awareness, as well as career planning process awareness.

Career development is a long process that includes choosing the right career path. In making the right decision and achieving the desired career goals, specific goals and specific stages must be taken into account. In other words, the development process does not always run in a straight line or in the direction of its potential, hope, and value. For that also provided guidance with career awareness program (career awareness) on guidance and counseling activities in primary schools (ASCA, 2008; Askew, 2000). The career guidance service in the context of primary school education is an effort to help the student know themselves and optimize their potential, thus putting the importance of career counseling services in schools to enhance child's recognition, understanding, and self-awareness.

(Carroll, Gillies, \& McMahon, 2001)The school helps the child to obtain career information, recognize the characteristics of self and the relationship between work and learning in everyday life. At the same time, the school curriculum should guard against gender bias regarding employment information. The child needs to be aware of how to change and to use the school experience to get information and better preparation to plan for the future. The child learns about the various professions in various ways, such as school, parents, peers, environment, and personal experience (Watson \& McMahon, 2005). Several inventions which are consistent with other show that career development learning is derived from all children's school experiences (Carroll, Gillies, \& McMahon, 2001).

Gibson states career theory by proposing the importance of role models in careers will help individuals guide their development (Gibson, 2004). The selection of careers and children's education is influenced by adult role models as well as by parents' expectations (D. M. Gibson, 2005). It reflects the important role that adults play in the development of childhood careers. In the African American study, found the self-efficacy of the boy is 
The Development of Career Learning Program with Modeling Techniques to Improve Student Career Awareness

predictable by modeling related to parenting careers, while the self-efficacy of girls is estimated by parents' emotional support (Alliman-Brissett, Turner, \& Skovholt, 2004). The inclusion of parents, family members, and other important adults in career exploration and modeling can help in to promote positive career development in children. The major foothold in the cognitive sociological theory approach derives from Bandura's social cognitive concepts (Hall, Lindzey, Loehlin, Manosevitz, \& Locke, 1985) which emphasize the complex ways in which behavior and environment interact with one another.

Magnuson and Starr states that children naturally have curiosity and seek to understand the world, look to others or models for counseling in seeking the identity, self-assessing with others' response to initiate self-exploration, watching people work and drawing conclusion about the nature or desire of work, and forming ideas about self and aspirations (Magnuson \& Starr, 2000). The development of a sense of curiosity and excavation to obtain information from observations and the role of models will lead the child to the development of children's interests and self-concepts resulted from the ability to plan careers.

Modeling is the process of teaching the child to behave voluntarily through observation and imitating of the desired behavior. Children usually imitate the behavior of people they like. In modeling techniques, there are several stages that can be used in providing services to individual or groups in order for the service delivery process to run properly. Bandura (Feist \& Feist, 2006) mentions four processes involved in learning through observation namely, 1) Attention process, child pays attention to what behaviors or actions are performed by the person to be imitated. Models will often be noticed if they are the same as the observer, a respected person or having a high status, having more ability, are considered strong and attractive. 2) retention process, after observing the behavior to be imitated and storing any information retrieved in the memory, then removing the memory when it is necessary. The retentional process stores information symbolically in two ways ie imaginatively and verbally. The imaginatively stored symbol is a description of the things that the model undergoes, can be taken and can be implemented after observational learning occurs. While verbal symbolization occurs cognitively and flexible. The complexity of information is stored cognitively and can be retrieved, repeated, and reinforced some time after observational learning occurs. 3) behavior reproduction process, in order to imitate the model, an individual must change the symbolic representation of the observation to the form of action. The emerging behavior must have something in common with the original behavior. In other words, affirming a person's motor skills will affect a person's likelihood of imitating a behavior that is seen either in whole or in part. The symbols obtained from the modeling will act as a template (mold) as a comparison of actions. During the training process, individuals observe their own behavior and compare it with the cognitive representation of the model experience. 4) motivation process, determine how capable the individual will do imitation but its reinforcement in terms of motivation that can spur the desire of individuals to meet the stages of learning.

The use of modeling techniques will be appropriate if it is used to increase career awareness as observing others performing an action that will have more responses which are not faulty imitating the behavior of others, but individual decides consciously to perform learned behaviors. Because through modeling techniques are expected students can increase career awareness by imitating the behavior that exists in the model. Models can be presented to the child through the use of video. In the implementation of the use of video media will help students in responding to what they see and hear, so messages from the content of the material contained in the video will be constructed by the brain of students and generate feedback in the form of questions about learning materials that will create interaction between students and teachers. Information will be easy to be understood because of the five senses, 
especially the ears and eyes that are used to absorb the information.

\section{METHOD}

Research and development approach conducted through several stages adapted: needs assessment, program planning, implementation of program, evaluation, and follow up. The following table of the implementation stage of the program.

\begin{tabular}{|c|c|c|}
\hline No & Activity & Supporting System \\
\hline 1 & Needs assessment & Career awareness instrument \\
\hline 2 & Program planning & Career awareness overview \\
\hline 3 & Implementation of program & SKLBK (Unit of guidance and counseling service) \\
\hline 4 & Evaluation & Career awareness instrument \\
\hline 5 & Follow up & $\begin{array}{l}\text { The result of program evaluation (effective career } \\
\text { guidance and counseling program with modeling } \\
\text { technique to improve career awareness) }\end{array}$ \\
\hline
\end{tabular}

Tabel 1. Implementation stage of career guidance program with modeling technique to improve student career awareness

This research used one group pre-test post-test design. This design is a pre-experiment design with the intention to see the response of the respondents before and after given guidance services.

Research population was all students of fifth grade Al-Fityan elementary school Aceh (53 students). The sampling technique used in this research was purposive sampling method. This selection was done on the basis of consideration of the career awareness level of the research population that was at a lower trend. Purposive sampling technique is selected after consideration of career awareness level of research population which is in medium and lowlevel tendency expressed through career awareness instrument. From the results of the dissemination of the instrument, one class is selected after hearing the advice of guidance and counseling teacher. The sample of research is fifth grade A student (26 students) with an average score of achievement lower than class B that is $69.92 \%$.

The career awareness scale of primary school students is self-developed by researchers, it requires validity and reliability tests to see the level of accuracy and appropriateness of each item statement in the instrument. Test item validity using Pearson Product Moment. The test of the validity of the statement item is done with the assistance of SPSS 16.0 for windows. Invalid items are eliminated, so the number of items before the test is 38 reduced to 25 items that will be used to uncover students' career awareness.

The reliability test of student awareness instrument in this study using Cronbach's Alpha. The reliability value of the student awareness instrument of 0,800 is in the category of highreliability degree. This proves that the research instrument can be used to reveal the level of student career awareness.

For data analysis, to determine the impact of the program, the statistical parametric analysis was used. This is based on the normality assumption of both normal-distributed pretest and posttest data. Statistical parametric analysis technique used to test in the research was t Sample Paired Test.

\section{RESULT AND DISCUSSION}

The career guidance program with the modeling technique was developed based on the result of the library study and the students' career awareness pre-test results. The method used in this study is to examine the real needs of students in the field through career awareness instruments. Based on the pre-test results, general profile awareness of career students has 
The Development of Career Learning Program with Modeling Techniques to Improve Student Career Awareness

been determined which then used as a foundation in formulating the needs of students.

The formulation of the program developed in the study is a program that is only implemented in one short period, about 1 month, and implemented by a counselor, in this case, is the researcher. The career guidance program with modeling techniques to improve career awareness of the fifth grade students of Al-Fityan elementary school Aceh was prepared by taking into the theoretical concepts. The development of career guidance program in research refers to Guidance and Counseling Development Guideline proposed by ABKIN (Indonesian Guidance and Counseling Association). Development programs respectively include: 1) rational, 2) description of needs, 3) objectives, 4) program components, 5) program objectives, 6) operational plans, 7) theme / topic development, 8) service units, and 9) evaluation.

In this study, the topics used to improve student career awareness are indicators of career awareness. The topics presented focuses on developing indicators: 1) skills to understanding others, 2) realizing the needs of growth and self-improvement, 3) understand the skills of using career information, 4) aware of the relationship of study and work, and 5) realize the process of making career planning. Using indicators as a service topic has been expected could improve career awareness as a whole and able to achieve optimal improvement.

The evaluation process of the implemented program consists of two kinds, namely evaluation of the process and results. Evaluation of the process is carried out to determine the suitability of the implementation of career guidance services activities with programs that have been formulated (Saripah, 2006). Evaluation of outcomes is seen from how student involvement in the service, counselor-student interaction, service delivery, and time. The evaluation of the results conducted to determine the level of achievement of the implementation of career guidance services with modeling techniques. The main indicator of success in terms of outcomes is the improvement in students as indicated by the increased level of career awareness of students on post-test results.

The pretest and posttest results indicate that there was a significant difference in student career awareness. The existence of significant differences through career guidance services with modeling techniques is known after the comparative processing of pretest and posttest results.

\begin{tabular}{ccc}
\hline Measurement & & Experiment (N=26) \\
\hline Pretest & $\mathrm{M}$ & 67 \\
& $\mathrm{SD}$ & 3,383 \\
\hline Posttest & $\mathrm{M}$ & 74 \\
& $\mathrm{SD}$ & 2,263 \\
\hline & $\mathrm{t}$ & 6,602 \\
\hline & $\mathrm{p}$ & $0,000(<0,05)$ \\
\hline
\end{tabular}

Table 2. Mean, standard deviation and sample paired test in pre-test and post-test

Based on table 2, the student's career awareness mean on the pre-test is 67 and 3.383 for standard deviation, while in the post-test that the mean 74 and standard deviation is 2.263. This indicates that the data variance is smaller because the standard deviation is less than the mean. There was also a significant difference between the mean score of pre-test and post-test.

Pre-test score and post-test at significance level $\alpha<0.05$, it can be concluded that the probability number Asymp. Sig. (2-tailed) student awareness before and after 0.000 , or probability under alpha $0.005(0.000<0.005)$. In addition, the paired t-test results also show that $\mathrm{t}$ arithmetic $6.602>\mathrm{t}$ table 1.708 which means there is a significant difference between 
the condition of students before and after obtaining career guidance services with modeling techniques. It can be concluded that career guidance with effective modeling techniques to improve student career awareness.

Increasing student awareness reflected that the students increasingly understood the importance of skills related to others, realizing the importance of growth and change in self, understanding the importance of using career information, being aware of the relationship of learning and working, and being aware of the process of making career planning. Increasing the student career awareness cannot be separated from the assistance of career guidance program with modeling techniques that have been prepared according to the needs of students.

Students need to be aware of how to change and use the school experience to get information and better prepared to plan the future (Watson \& McMahon, 2005). Students learn about the various professions in various ways, such as schools, parents, peers, the environment, and personal experience. The study suggests the results in African American studies, they find self-efficacy of boys is predictable by modeling related to parenting careers, while the self-efficacy of girls is estimated by parents' emotional support (Alliman-Brissett et al., 2004).

Through modeling, students can understand the skills associated with others; realizing the importance of using career information skills; be aware of learning and work relationship; as well as being aware of the process of making career planning. Perry \& Furukawa said modeling as a learning process through observation in which the behavior of an individual or group, as a model, acts as a stimulus for thoughts, attitudes, or behaviors as part of another individual observing the model shown (Abimanyu \& Manrihu, 1996).

Adi Putra's research also states that the use of modeling techniques in improving child care planning is effective (Adiputra, 2015). The purpose of the study is to direct the child to be able to plan a career by understanding the interests and potential of child development.

Through modeling using individual media will learn experiences experienced by themselves and the experience of others. The individual learning process is not only obtained through personal experience but observation of the behavior of others. Students who are able to plan for the future because they have realized self-knowledge and the importance of achieving school and work will make other students more confident to start realizing selfknowledge and achieving school and work comparable to what other students have done.

\section{CONCLUSION}

Overall, this research has fulfilled the goal of producing career guidance program with modeling techniques to improve student career awareness. Career guidance program with modeling technique is a guidance activity developed based on the structure of the program which explains the link between the stages of career counseling with modeling techniques aimed to improve career awareness generally. It can be assumed that career guidance service with modeling techniques is empirically proven to be effective in raising career awareness.

\section{REFERENCE}

Abimanyu, S, \& Manrihu, M.T. (1996). Teknik Relaksasi dalam Konseling. Jakarta: Kencana Perdana Media Group.

Adiputra, S. (2015). Penggunaan Teknik Modeling Terhadap Perencanaan Karir Siswa. Jurnal Fokus Konseling, 1(1).

Alliman-Brissett, A. E., Turner, S. L., \& Skovholt, T. M. (2004). Parent support and African American adolescents' career self-efficacy. Professional School Counseling, 124-132. 
The Development of Career Learning Program with Modeling Techniques to Improve Student Career Awareness

Amundson, N. E., Harris-Bowlsbey, J., \& Niles, S. G. (2005). Essential elements of career counseling: Processes and techniques. Pearson/Merrill/Prentice-Hall.

ASCA. (2008). Why elementary school counselors. Retrieved from http://www.schoolcounselor.org/content.asp?contentid=230

Askew, M. (2000). Elementary school career education-the need, basics, examples, and guidelines. Retrieved 7/24/2009 at http://www. articlesbase. com/educationarticles/elementary-school-careereducation-the-need-basics-examples-and-guidelines197824. html.

Carroll, J., Gillies, R., \& McMahon, M. (2001). Career dreams: Occupational aspirations of year six children. Australian Journal of Career Development, 25-31.

Emmett, J. D. (1997). The preparation of elementary school counselors for career development: What exists-what is needed. Journal of Career Development, 23(3), 177187.

Feist, J., \& Feist, G. J. (2006). Theories of Personality (6th ed.). New York: McGraw Hill.

Gibson, D. E. (2004). Role models in career development: New directions for theory and research. Journal of Vocational Behavior, 65(1), 134-156.

Hall, C., Lindzey, G., Loehlin, J. C., Manosevitz, M., \& Locke, V. O. (1985). Introduction to theories of personality. John Wiley\&Sons.

Johnson, L. S. (2000). The relevance of school to career: A study in student awareness. Journal of Career Development, 26(4), 263-276.

Magnuson, C. S., \& Starr, M. F. (2000). How early is too early to begin life career planning? The importance of the elementary school years. Journal of Career Development, 27(2), 89-101.

Muro, J. J., \& Kottman, T. (1995). Guidance and counseling in the elementary and middle schools: A practical approach. Brown \& Benchmark Madison, WI.

Nazl1, S. (2014). Career development of upper primary school students in Turkey. Journal of Psychologists and Counsellors in Schools, 24(1), 49-61.

Saripah, I. (2006). Program Bimbingan untuk Mengembangkan Perilaku Prososial Anak (Thesis). Universitas Pendidikan Indonesia.

Stead, G. B., \& Schultheiss, D. E. P. (2003). Construction and psychometric properties of the Childhood Career Development Scale. South African Journal of Psychology, 33(4), 227-235.

Stroeher, S. K. (1994). Sixteen kindergartners' gender-related views of careers. The Elementary School Journal, 95(1), 95-103.

Suherman, U. (2013). Bimbingan dan Konseling Karir Sepanjang Rentang Kehidupan. Sekolah Pascasarjan UPI: Bandung.

Unicef. (2012). Indonesia Laporan Tahunan 2012. Jakarta, UNICEF Indonesia.

Watson, M., \& McMahon, M. (2005). Children's career development: A research review from a learning perspective. Journal of Vocational Behavior, 67(2), 119-132.

Worzbyt, J. C., O’Rourke, K., \& Dandeneau, C. (2003). Elementary school counseling: A commitment to caring and community building. Routledge. 
Copyright Holder:

(C) Keumala, E., Nurihsan J., \& Budiamin A.(2018)

First Publication Right :

(C) Islamic Guidance and Counseling Journal

This article is under:

(ㅇ)(1) (2) 